\title{
APORTACIÓN DOCUMENTAL AL ESTUDIO HISTÓRICO-ARTÍSTICO DEL ARCIPRESTAZGO DE PONTE BELUSO
}

\author{
Por \\ Ma ISABEL PÉREZ PIÑEIRO
}

Antes de comenzar, es conveniente tener en cuenta que, con este trabajo se ha pretendido una aproximación al estudio histórico-artístico de una zona que no está lo suficientemente estudiada. Los datos que se aportan, son una base para futuros trabajos de investigación, con los que se ambiciona un mejor conocimiento del arciprestazgo de Ponte Beluso.

\section{ENCUADRE GEOGRÁFICO}

El arciprestazgo de Ponte Beluso pertenece a la Diócesis de Santiago de Compostela. Se encuentra al Sur de la provincia de A Coruña, al margen derecho del río Ulla y en la parte septentrional de la Ría de Arousa. Forman parte de el catorce parroquias pertenecientes a dos ayuntamientos: Boiro y Rianxo.

Al municipio de Boiro pertenecen las parroquias de San Cristóbal de Abanqueiro, San Pedro de Bealo, Santa Eulalia de Boiro, Santa María del Castro de Cabo de Cruz, San Vicente de Cespón, San Andrés de Cures y, San Juan de Macenda.

Al de Rianxo: Santa Eulalia de Araño, Santa María de Asados, Santa María de Isorna, Santa María de Leiro, Santa Columba de Rianxo y el Divino Salvador de Taragoña.

"CUADERNOS DE ESTUDIOS GALLEGOS", Tomo XLVII, Fascículo 113, Santiago 2000. 


\section{METODOLOGÍA, CRONOLOGÍA Y FUENTES}

La metodología empleada para la realización de este trabajo ha comenzado por el vaciado sistemático de la documentación existente mediante fichas, en las que se recogía: la parroquia, la obra, la fecha, el autor, en caso de que fuese citado, y la transcripción de la noticia.

Para la clasificación de dicha información se ha optado por agruparla en seis apartados diferentes: el primero destinado a la arquitectura, el segundo para la escultura, el tercero para pintura, el cuarto para la orfebrería, el quinto para varios y, se ha considerado necesario, debido a la cantidad de visitas, la creación de un sexto apartado; dentro de este último, se han hecho a su vez otros cinco subapartados, en los que se organizan los mandatos de las visitas, según el contenido al que hagan referencia: arquitectura, escultura, pintura, orfebrería y varios.

Antes de continuar con este apartado es importante destacar la fecha en que se fundó este arciprestazgo. Su creación aparece publicada en el Boletín Oficial del Arzobispado del mes de Julio de 1982.

Ponte Beluso se crea a partir de las parroquias procedentes de tres arciprestazgos distintos: Iria Flavia, Postmarcos Arriba y PostmarcosAbajo. A la jurisdicción de Iria Flavia pertenecían: Santa Eulalia de Araño, Santa María de Asados, Santa María de Isorna, Santa María de Leiro y, Santa Columba de Rianxo. A la de Postmarcos de Arriba: San Pedro de Bealo, San Vicente de Cespón, San Andrés de Cures, San Juan de Macenda y, el Divino Salvador de Taragoña. Finalmente a Postmarcos de Abajo le correspondían: San Cristóbal de Abanqueiro, Santa Eulalia de Boiro, Santa María del Castro de Cabo de Cruz y, Santiago de Lampón.

Del mismo modo, es muy importante tener en cuenta que, en el apartado del aporte documental, no están incluidas las parroquias que habían pertenecido al arciprestazgo de Postmarcos de Abajo, ya que el vaciado de las mismas ha sido realizado por Doña María Dolores Reiriz Figueiras en la tesis de licenciatura, Aportación documental al estudio históricoartístico del arciprestazgo de Postmarcos de Abaixo, (siglos XVI al XX), defendida en 1988.

La documentación existente en los archivos parroquiales abarca desde el siglo XVI hasta el siglo XX.

Los libros de Fábrica más antiguos encontrados son: uno de Fábrica de Araño (1544-1612), al que le faltan algunas hojas al principio y al final,

"CUADERNOS DE ESTUDIOS GALLEGOS", Tomo XLVII, Fascículo 113, Santiago 2000. 
su estado no es muy bueno, lo que a veces dificulta su lectura; otro de Bealo (1612-1627) y uno de Leiro (1622-1656). De los siglos XVIII, XIX y XX, son los más abundantes. En algunas parroquias incluso se ha podido llegar hasta la actualidad: Libro de Cuentas de la Fábrica de Araño (1941-1995) y el de Cuentas de Rianxo (1976-1996).

En todas las parroquias hay libros de Cofradías: el más antiguo es el que se encuentra en el archivo parroquial de Araño, perteneciente a la Cofradía de San Juan Bautista (1626-1690).

No se conservan, o no llegaron a existir, libros de Visita exclusivamente, éstas se encuentran reflejadas dentro de los libros de fábrica y cofradías.

Los libros de inventario son escasos, sólo se localizan en Cespón (19081932), Bealo (1981) y Rianxo (1981). Los inventarios suelen aparecer también dentro de los libros de Fábrica y Cofradías.

Los libros de Veredas existir en varias parroquias: Araño (1829-1892), Bealo (1829-1892), Cures (1825-1855); en ellos se recogen los mandatos y órdenes del arzobispado y de Roma-son interesantes a la hora de entrever la realidad del momento-.

En algunas parroquias se han encontrado libros de inquilinato: Araño (1861), Bealo (1860-1980), Cespón (1847-1951) y, Macenda (1879-1989); en éstos están anotadas todas las reparaciones en la casa parroquial y sus estancias anexas.

Son varios, también, los libros de fundaciones; en estos se recogen las fundaciones de misas, obras pías y de capellanía; el más antiguo es el que se conserva en el archivo parroquial de Taragoña (1661-1708) y, él más reciente, lo posee la parroquia de Santa María de Isorna (19091930).

Existe un único caso en todo el arciprestazgo de un Libro de Dotación de Huérfanas (1836-1916), encontrado en el archivo parroquial de Rianxo.

\section{ARQUITECTURA}

En este apartado se va a tratar de la arquitectura; se atenderá a todo tipo de obras, tanto de nueva planta como reformas, restauraciones u obras de mantenimiento; estas últimas, es decir, blanquear, retejar, repicar paredes, hacer tarimas, allanar las losas de la iglesia, reparaciones en los atrios,

"CUADERNOS DE ESTUdIOS GALLEGOS", Tomo XLVII, Fascículo 113, Santiago 2000. 
abrir y tapiar puertas y ventanas, son las más frecuentes. Otros trabajos de mayor envergadura pueden ser la construcción de las torres de algunos templos, como ocurre en Leiro (1731-1732), Rianxo (1739), Isorna (1744), Cures (1745) o los trabajos en el campanario de madera de Taragoña (17271728), en la espadaña de la capilla de Guadalupe de Rianxo (1898), en la fábrica de las tribunas, en Leiro (1731-1732), Rianxo (1740-1741), Isorna (1743-1744); también se atiende a labores como la de ensanchar la iglesia de Cures en 1686 y su proyecto de construcción (1867-1868), levantar una capilla nueva en la iglesia de Cespón (1756), la capilla de las Nieves de Macenda (1741), y reedificar la capilla de los Milagros deAraño (1808 y 1972), y la sacristía de Bealo (1758).

En estas obras participan un sin número de maestros de obras, canteros y carpinteros, razón por la cual vamos a enumerar los que se consideran de mayor interés.

No se puede hablar de un foco claro del que provengan dichos artistas, hay maestros de Noia, Padrón y otras localidades, siendo los de la provincia de Pontevedra los más numerosos -Catoira, Moraña, Estrada, Pontevedra o Cotobade-, quizás debido a su proximidad geográfica.

Para una mayor claridad, se comenzará por los maestros más destacados de fuera del arciprestazgo, para atender al final a los locales.

Una mención especial es la que merece el maestro de cantería, Benito de Monteagudo ${ }^{1}$, vecino del Valle de Quireza. Según Bonet Correa es uno de los tres Monteagudos conocidos de la época ${ }^{2}$. Este, en el año 1676, se hace cargo de reedificar la sacristía de la iglesia de San Pedro de Bealo:

"Mas da por descargo quatrocientos reales vellón que dio a Benito de Monteagudo, vezino del Valle del Quireza, maestro de cantería por hazer la sacristía que tiene dicha Iglesia, por ser tan conveniente».

\footnotetext{
${ }^{1}$ COUSELO BOUZAS, J.: Galicia Artística en el siglo XVIII y primer tercio del siglo XIX. Santiago. 1932, p. 463.

${ }^{2}$ «Los Monteagudos conocidos de su época son tres: Domingo, Benito y Sebastián... El segundo es Benito Monteagudo, que en 1712 y 1713, trabajó también en Betanzos, donde construyó la capilla del Rosario de la Iglesia de Santo Domingo». BONET CORREA, A.: La arquitectura en Galicia durante el siglo XVII. Madrid. 1966, p. 342.
}

"CUADERNOS DE ESTUDIOS GALLEGOS", Tomo XLVII, Fascículo 113, Santiago 2000. 
Por su parte, el cantero noiés Pedro Malváriez, al que Couselo califica de escultor ${ }^{3}$, figura en las obras que hace en la iglesia y sacristía de San Pedro de Bealo, en 1685, como cantero y vecino de Noia ${ }^{4}$ :

«Iten da por descuento ciento y treinta y quatro reales de vellón que pago a Pedro Malvares, cantero, vezino de la villa de Noya, por las obras y labor que hizo en dicha Iglesia, alrededor de ella, sacristía, por adentro y encima de ella, las quales obras y labor son el aver sollado y losado el terreno y ámbito de dicha sacristía a la esquadria; levantado un escalón a la entrada del presbiterio; mullido todas las sepulturas de dicha Iglesia, puéstolas por orden y regla, añadídoles piedras para su mayor concierto, hecho entierros separados para párvulos y de algunos adultos menores para mejor cabida y contenta de todos los naturales; movido los altares colaterales, haziéndolos de nuevo y movídoles diferentemente de lo que antes estaban por no tener capacidad para celebrar en ellos; hecho la pila baptismal con sus gradas, pedestal, basa columna y sumidero con perfecçión y arte, por ser indecente u quebrada la de que se usaba antes, según ello lo denota y está arrimada; y así mesmo la pila del agua bendita con su columna y basa, en que se sustenta; una fortificación por la parte del nordés pegado a dicha Iglesia que las advenidas y continuación del agua bajada de las corrientes de dicha Iglesia y su alto sofocaban los cimientos de ella, con que se aseguró, haze adorno las defiende y sirve de asiento y por la parte arruynada de los cimientos asi mismo de dicha Iglesia y la cal arriba referida la embebió en estas cosas.

Mas da por descargo nobenta reales del mantenimiento de tres meses en días feriados que ocupó dichas obras, contado cada día de gasto a real, importa dichos nobenta reales».

\footnotetext{
${ }^{3}$ «Figura en la Unica como escultor de Noya, de 43 años de edad, casado con Bernarda Vázquez, de 50; tenían una hija de 20 años llamada $\mathrm{M}^{\mathrm{a}}$ Manuela y otra menor de edad, dándole de sueldo al escultor cinco reales. Era por lo tanto escultor de cierta importancia, a juzgar por lo que cobraba». COUSELO BOUZAS, J.: Galicia Artística...op. cit., pp. $348-440$.

${ }^{4}$ «....a Pedro Malvares, cantero, vezino de la villa de Noya, por las obras y labor que hizo en dicha Iglesia, alrededor de ella, sacristía, por adentro y encima...». Véase este trabajo, p. 290.
}

"CUADERNOS DE ESTUDIOS GALLEGOS", Tomo XLVII, Fascículo 113, Santiago 2000. 
A su vez, Jacobo de Fontenla, de Santa María das Fragas, jurisdicción de Cotobade (Pontevedra), trabaja en la parroquia de San Vicente de Cespón, en 1701, abriendo dos ventanas en la iglesia:

"Mas da por descargo cien reales que llevó el maestro cantero Jacob de Fontenla, vezino de la feligresía de Santa Marina das Fragas, jurisdizión de Cotobade, por las dos ventanas que abrió en esta Iglesia Parroquial, la una por el respaldo del retablo de la capilla maior, y la otra sobre el arco principal de dicha capilla, para dar lus y claridad a dicha Iglesia».

Dos años más tarde, en 1703, se encuentra de nuevo en Cespón, levantando un arco y el campanario de la capilla de San Roque:

«Mas da por descargo trecientos reales que pago a Jacob de Fontenla, maestro de cantería, vecino de la jurisdicción de Cotobade, por hacer el arco en la capilla de San Roque. Con mas ciento y veinte reales por hacer el campanario y penales de cantaría de dicha capilla de San Roque y tejarla que en todo son quatrocientos y veinte reales».

El mismo artista figura como maestro de cantería en las obras de la capilla de Nuestra Señora y Animas, en el osario añadido a la iglesia parroquial por la parte norte, entre 1705-1706, en las de reedificación de las paredes de la iglesia parroquial (1708), en las del cuerpo, coro y torre de la iglesia de San Pedro de Bealo (1718) y, en las del remate de la cornisa de la iglesia de el Divino Salvador de Taragoña (1719):

"Mas da por descargo mil sieteçientos y setenta reales que entregó dicho mayordomo a Jacobo de Fontenla, vezino de la feligresía de Santa Marina das Fragas, maestro de cantería, por la obra que ha hecho de la capilla de Nuestra Señora y Animas y osario añadido a esta parroquia de Cespón por la parte del norte, que aunque costó dicha obra y otras algunas que hizo en dicha Iglesia, mucho más dinero lo pagó Christoval de Romay, fabriquero de dicha fábrica y se le pasó en descargo en sus quentas como de ellas consta; y al mayordomo desta cofradía solo se le descargan por esta razón los dichos mil

"CUADERnOS DE ESTUdios GALLEGOS", Tomo XLVII, Fascículo 113, Santiago 2000. 
siete cientos y setenta reales referidos que entregó a dicho maestro y de el sacó reçivos».

«Mas da por descargo quinientos y sesenta reales que pagó a Jacobo de Fontenla, maestro de cantería, vecino de Santa Marina das Fraguas, para en quenta de las obras que ha hecho en esta yglesia de reedificar las paredes y costados de ella, haçer el zemeterio y otras más obras, con más lo da de otras partidas que además de las dicha pagó a dicho Jacobo de Fontenla para dichas obras; como son duçientos reales, que constan de un recibo de dicho Jacobo que tiene y presentó este mayordomo, su fecha de treinta de mayo de sietecientos y ocho, con más cien reales que refiere otro recibo de treinta de junio de dicho año. Mas cinquenta y un real, de otro recibo firmado de dicho Jacobo, sin fecha y otro de trescientos y cinquenta y dos reales, su fecha de siete de setiembre de dicho año de sietecientos y ocho, que todas estas partidas juntas importan mil ducientos y sesenta y tres reales».

"Mas tres mil reales que dio a Jacobo Fontenla, en que fue concertado el cuerpo de la Iglesia, por quanto aunque hiço tanvién el coro y la torre, se le conçertó y pagó aparte, sin que fuese del dinero de la Iglesia, si bien a costa de los patrones, cura y cofradia».

"Mas se le admiten en data quinientos y treinta y ocho reales y treinta maravedis, los mesmos que se emplearon por mano de dicho rector en las cosas siguientes: ducientos y ochenta y un reales y veinte y dos maravedís que pagó a Jacobo de Fontenla, maestro de cantaría, a quenta / de quinientos reales en que se le ajustó y remató la cornisa del costado de la Iglesia que mira al medio día, ventanas rasgadas de cantaría que hizo en dicho costado; el arco principal del cuerpo de la Iglesia y la media pared que hizo encima de dicho arco, con su cruz».

También en San Pedro de Bealo, en 1719, aparece trabajando Francisco Fraga, maestro de obras, que es posible que sea el que cita Couselo ${ }^{5}$ y que, a su vez, menciona Murguía ${ }^{6}$. Dicho maestro se ocupa del atrio de la parroquial:

${ }^{5}$ COUSELO BOUZAS, J.: Galicia Artística...op. cit., p.355.

${ }^{6}$ MURGUÍA, M.: El Arte en Santiago durante el siglo XVIII. Santiago. 1884, p. 215.

"CUADERNOS DE ESTUDIOS GALLEGOS", Tomo XLVII, Fascículo 113, Santiago 2000. 
"Mas duzientos y diez y ocho reales que dio a Francisco da Fraga, maestro que hizo el atrio».

Otro de los maestros que trabajan en este arciprestazgo es Ignacio Barros, que ejecuta la obra del campanario de la iglesia parroquial de Santa Columba de Rianxo, en 1739; es probable que sea familiar del maestro de cantería Antonio Barros ${ }^{7}$, natural de Rianxo.

También se debe citar a un artista que trabaja en Santa María de Isorna en 1741, en la obra de la iglesia, torre y sacristía. Se trata de Pascual Antonio de la Torre y Ferreiro ${ }^{8}$, uno de los pocos artistas que aparecen con el título de maestro arquitecto:

"Mas de le bonifican en descargo tres mil ducientos sesenta y cinco reales que dio y entregó a Pasqual Antonio de la Thorre y Ferreiro, maestro arquitecto para en quenta de la cantidad en que está ajustado por el hazer la Iglesia, Thorre, Sacristía y mas que contiene el ajuste, todo ello consta por recibo que exsibe de dicho maestro».

Asimismo, Juan de Fontenla ${ }^{9}$, maestro natural de Dimo (Pontevedra), que trabaja en la obra de cantería de la iglesia parroquial de Cordeiro (Pontevedra), trazada por Antonio Barros, natural de Rianxo. Enlosó la Iglesia de Santa María de Isorna en 1746-1747. A pesar de la coincidencia de apellidos con Jacobo de Fontenla y, aunque ambos son vecinos de la provincia de Pontevedra, no hay datos suficientes para afirmar que tengan relación:

\footnotetext{
${ }^{7}$ COUSElo BOUZAS, J.: Galicia Artística... op. cit., p. 202.

${ }^{8}$ «Cerca de la villa de Padrón, distante unos cinco kilómetros, a la derecha del río Ulla, hay la parroquia de San Julián de Laiño, la cual cuenta con una iglesia en forma de cruz latina, amplia y con bóveda de cantería. Es edificación del siglo XVIII. Se había mandado reedificar en tres autos de Visita, 1716-32 y 40. Por fin determinaron hacerla para lo cual pidieron la traza al P. Fr. Manuel de la Presentación, carmelita del convento de Padrón... Se empezó la obra, en conformidad con la planta, por administración, siendo maestro Manuel de la Torre Ferreiro; pero en 1743 se le hizo a éste contrato de lo que faltaba». COUSELO BOUZAS, J.: Galicia Artística...op. cit, p. 630.

Es posible que Manuel y Pascual Antonio de la Torre Ferreiro sean hermanos, ya que coinciden en apellidos, en cronología y trabajan en áreas geográficas próximas.

${ }^{9}$ COUSElO BOUZAS, J.: Galicia Artistica... op. cit., pp. 352-353.
} 
"Primeramente da en descargo tres cientos y quarenta reales vellón, los mesmos que pago a Juan de Fontenla, maestro de cantería, vezino de la feligresía San Pedro de Dimo, por rasón del travago que tubo por en enlosar la yglecia y hacerla portadilla del atrio desta feligresía. Según consta de recibo del mismo Fontenla».

Otros artistas que deben ser mencionados son Domingo y Esteban Ferreiro, maestros de cantería, según los datos que aparecen en la documentación consultada. Lo que no coincide es el lugar de procedencia de ambos, ya que, según Couselo Bouzas ${ }^{10}$, Domingo es vecino de Padrón (A Coruña) y Esteban de Caldas (Pontevedra). Esteban sería el de mayor actividad, ya que había participado en la obra de la Iglesia de Santa María de Caldas, en la de San Cristóbal de Briallos (Pontevedra), en la de Santa María de Gonzar (Arzúa) y en San Julián de Bastavales ${ }^{11}$. Los dos Ferreiro, participan en la misma obra, la de una Capilla de la Iglesia de San Vicente de Cespón, en el año 1756:

"Mas trescientos reales que entregó a Domingo Antonio Ferreiro para ayuda de la obra de la capilla consta por recibo firmado suio, su fecha diez y seis de abril del año pasado de mil setecientos cinquenta $y$ seis, $y$ este es el recibo que se menciona en la partida de los quatrocientos y treinta que dio en data Francisco de Souto.

Mas trescientos cinquenta y cinco reales que entregó a Esteban Ferreiro, cantero para ayuda de la obra de dicha capilla. Consta por recibo firmado suio, su fecha veinte y cinco de septiembre del año pasado de treinta y seis.

Mas cien reales que entregó al mesmo Esteban para el mismo efecto de la capilla, según recibo firmado suio. Su fecha treinta y uno de octubre pasado de cinquenta y seis».

\footnotetext{
${ }^{10}$ COUSELO BOUZAS, J.: Galicia Artística... op. cit., pp. 315-317.

${ }^{11}$ COUSELO BOUZAS, J.: Galicia Artística... op. cit., pp. 315-317.
} 
El maestro de cantería natural de Padrón, Bernardo Arosa, que había trabajo en la iglesia y sacristía de Santa Eulalia de Vilacoba ${ }^{12}$, repara la bóveda de la parroquial de Santa María de Isorna en 1762-1763:

«También se le admiten quinientos y cinquenta reales vellón que pago a Bernardo Aroza, maestro de cantería, vezino de la villa de Padrón por el trabaxo del reparo de la Bóveda de la Iglesia. Según recibos que exivió del susodicho».

En Santa María de Asados se encuentra Isidro Gontade ${ }^{13}$, vecino de San Félix de Estacas (Cuntis) y maestro de cantería, que, en mayo de 1794, concluyó la torre la iglesia, ya que la vieja estaba arruinada; también levantó la bóveda y finalizó la capilla de Santa Lucía:

«En maio de 1794 se remató la torre de esta Iglesia, por esta medio arruinada la vieja, en Isidoro Gontade, maestro vezino de San Félix de Estacas y al mismo tiempo la bóveda de la Capilla de Santa Luzía, a todo coste sin darlos vezinos ni la Iglesia, maderas, estada, ni más servicio que carretar la piedra en la cantidad de onze mil y quince reales y además de ello dar la cal necesaria. Hizose la obra tan buena como se ve y se acabó la capilla de Santa Lucía, se entienda el coro, aunque pequeño pagose al maestro la cantidad de los onze mil y quinientos reales que ha dado rezibo y está en este libro».

Si bien como oficial, como cierre de este grupo, se debe citar a Francisco Gómez, el cual, en 1739, trabaja en la torre de las campanas de Rianxo. Puede que sea el mismo que recoge Murguía ${ }^{14}$ :

${ }^{12}$ Hizo contrato en Santiago el 13 de Enero de 1735, D. Juan Antonio de Neira, Oficial del Santo Oficio, en nombre de los vecinos de Santa Eulalia de Vilacoba, con Bernardo Arosa maestro de cantería, vecino de Padrón, de la obra de edificación de la capilla mayor y sacristía de la expresada parroquia a cimentis». COUSELO BOUZAS, J.: Galicia Artística...op. cit., p. 194.

${ }^{13}$ COUSELO BOUZAS, J.: Galicia Artística... op. cit., pp. 392-393.

${ }^{14}$ La única referencia citada por este autor es la fecha de 1740. MURGUÍA, M.: El Arte en Santiago...op. cit., p. 217.

"CUADERNOS DE ESTUdios GALLEGOS", Tomo XLVII, Fascículo 113, Santiago 2000. 
«Y a Francisco Gómez también ofizial como lo son todos los más expresados menos el albañil que va de dar ciento veinte y dos reales».

Entre los artistas locales, menos significativos que los ya citados, deben resaltarse los nombres de:

Juan Campos, maestro cantero de Rianxo, que en 1693, hace obras en la iglesia de San Vicente de Cespón, aunque se desconoce de qué tipo. La documentación consultada apunta hacia atrás, puesto que en 1700 se anota la posibilidad de que esa primera obra sea el atrio que, en 1700, dicho maestro no concluye:

"Mas da por descargo ciento y treinta y seis reales que ha de pagar al maestro cantero que acavare el atrio de esta Iglesia de Cespón, que no acavó el cantero Juan Campos, de Rianxo, ni cumplió el contrato, según la obligación y zédula que hiço. Por quanto tocó a esta cofradía duçientos reales y dellos solos sesenta y quatro se vaxaron en las quentas que dio Luis de Reyno y ahora para ajustarlos se vaxan los dichos ciento y treinta y seis reales».

Alonso Reboredo, maestro de cantería, vecino de la feligresía de Santa María deAsados, que se desplaza entre 1731-1732 a una parroquia cercana, Santa María de Leiro, para trabajar en la obra de la torre de las campanas:

"Iten ciento y cinquenta y nuebe reales que dio a Alonso Reboredo, maestro de pedrería para aiuda de hacer la torre de las campanas».

Asimismo, realizó para la iglesia de su parroquia varios trabajos: el arreglo del piso en 1749; el enlosado de la iglesia en 1750; y, en 1751, 1757 y 1759 el retejado de la parroquial y la capilla de Santa Lucía:

"Iten se le bonifican trecientos noventa y tres reales que por recivos acredita aver entregado a Alonso Revoredo, cantero, para quenta de los quinientos y noventa reales en que se le remató el lampear y piso de la Iglesia».

"Iten quinientos y ocho reales vellón, los ciento diez y siete y treinta y dos maravedís que le entregó Francisco Mella y Francisco Riveyro, los mismos que resultaron de alcanse contra los susos dichos en 
la última revisión de quentas que ha avido que unos y otros entrego a Alonso de Reboredo, maestro de cantería por el trabajo de enlosar la Iglesia, según recibo que exsivió».

Martín Frieiro, maestro albañil de Rianxo, que realiza únicamente labores de mantenimiento - blanquear y retejar- en Santa María de Asados y Santa Columba de Rianxo, entre las fechas de 1884 y 1900.

El cantero Ricardo Iglesias de Rianxo, quien, entre 1890 y 1894, efectúa las obras de mantenimiento en la iglesia y capilla de Guadalupe de dicha localidad, y, en el año de 1898, hace la espadaña de dicha capilla:

«NOTA: En treinta y uno de Diciembre de mil ochocientos noventa y siete un ciclón muy fuerte derribó la espadaña de la Capilla aplastando el techo, la tribuna y más que encontró a su paso, reduciéndolo todo a escombros por lo que hubo que restaurar todos los daños ocasionados y se invirtieron los materiales y jornales que a continuación se expresan en la forma siguiente».

"Al cantero Ricardo Iglesias de esta misma, / por hacer la espada$\tilde{n}$ a de la capilla doscientos ochenta y ocho reales».

También cabría citar en este apartado al maestro carpintero Bonifacio Canabal, que, entre 1740-1741, hace la tribuna para la iglesia parroquial de Rianxo, y, entre 1743-1744, levanta la tribuna de la iglesia parroquial de Santa María de Isorna:

"Mas trescientos y diez y ocho reales de vellón que llevaron Pedro Dieste y Bonifacio Canaval, carpinteros, los ducientos y noventa y siete por la echura de esta tribuna y los restantes por el travajo que tubieron en hazer los cabeletes y hazimbras para el arco".

"Consiguientemente dicho rector da en data ducientos setenta y dos reales que pago a Bonifacio Canabal, vezino de la villa de Rianjo, maestro de carpintería, por hacer la tribuna de la Iglesia, con su valaustrada, en cuia cantidad dicho maestro remató la referida tribuna. Según recibo». 


\section{ESCULTURA}

Dentro de este apartado se recogen las noticias sobre las obras realizadas en retablos y altares -asentamiento, composición y restauración-; la hechura y reparación de imágenes; un número considerable de andas; en menor medida Cristos y, la realización de cruceros.

En este arciprestazgo de Ponte Beluso hay dos focos que, con diferencia sobresalen respecto a otros que podemos calificar de menores o que, simplemente, no se deben denominar focos. Uno de estos es Santiago, de gran fuerza en esta zona, tanto por su cercanía como por la comunicación relativamente fácil, además de ser el foco artístico gallego más relevante; lo mismo ocurre con Noia, en esta zona se encuentran bastantes obras de maestros de esa villa. Un tercer foco podría ser, aunque muy lejos de los dos anteriores, el local, los ejemplos más claros son los Núñez de Boiro. Existen casos aislados como es el ya citado Juan Pérez de Oeste; de Pontevedra Benito Collazo; ó Francisco Vicente de Riobo del Coto de Sobrán, que en 1671 hace el retablo mayor de Bealo.

Entre los artistas que figuran en la documentación consultada, cabe destacar a entalladores y escultores de la talla de Miguel Romay -quizás uno de los más importantes del arte gallego-o, al aragonés Juan Bautista Celma, al entallador santiagués Antonio Afonsín, al escultor José Vázquez de Córdoba, Jacobo Quinteiro, Juan Pérez, al pintor Benito Collazo, a Francisco Núñez, Alonso Fernández, Hipólito Fernández Gudín, Bernardo del Río Señoráns, José Benito Malvárez y Juan Novo.

El primero en orden cronológico que debe ser destacado es Juan Bautista Celma ${ }^{15}$, este artista aragonés que ha cultivado varios géneros -pintura, talla en piedra y madera, rejería e incluso funde campanas- y que, según Pérez Constanti, es el más fecundo de su tiempo, no solo en Galicia, sino también en España, realiza el retablo de la parroquial de Santa Eulalia de Araño en 1588-1589:

«Primeramente dio por descargo el dicho Gregorio do Aydo, tener ya pagado a Baptista Selma, pintor, para en pago del Retablo treinta y

${ }^{15}$ PÉREZ COSTANTI, P.: Diccionario de artistas que florecieron en Galicia durante los siglos XVI y XVII. Santiago. 1930, pp. 115-134.

"CUADERNOS DE ESTUDIOS GALLEGOS", Tomo XLVII, Fascículo 113, Santiago 2000. 
ocho ducados, lo qual mostró por cartas de pago y recados vastantes que son y montan quatrocientos y diez y ocho reales.

Dio mas por descargo aver gastado quando fue hazer el conçierto del Retablo y con el hazer de la escritura y con yr y vuelta a Santiago, llebar la segunda paga para el retablo, aver gastado en todo questo seis reales y medio.

Dio mas por descargo aver gastado quando ha por el retablo diez y seis reales que dio de aluguero por dos carros que lo traxeron con mas un real que dixo avía gastado con que son ansi diez y siete reales.

Mas seis reales y medio que dio por cuenta a aya gastado con los carpinteros que vinieron sentar y componer el retablo, la primera vez resto en darles de comer.

Dio mas por descargo aver gastado çera entreambos que monto ochenta y quatro reales y medio y mas un quartillo».

Otro entallador, Lucas Serrano ${ }^{16}$, que trabaja en la capilla mayor de la catedral $^{17}$, realiza en San Pedro de Bealo los altares colaterales en 1673:

«Primeramente da por descargo sietecientos y treçe reales menos seis maravedis, por lo que costaron los coletorales, guardapolvos dellos y acheros, clavos y clavijas para asentarlos, que llevó Lucas Zerrano, maestro de architectura vezino de la villa de Villagarcia, en esta manera: los sietecientos dicho Lucas Zerrano, ocho reales menos seis maravedis el herrero por dichos clavos y clavijas y cinco a cumplimiento de la resta de las barcaxes de dicho mayordomo de averle conducido la partida referida a su casa».

${ }^{16}$ PÉREZ COSTANTI, P.: Diccionario de Artistas...op. cit., pp. .512-514.

${ }^{17}$ Nese mesmo ano de 1661 Pedro Taboada está realizando capiteis para esta obra e Brais do Pereiro, unha serie de medallóns. Tal tipo de traballos mantéñense nos anos seguintes; Mateo de Prado, Pedro del Valle, Juan Cabrera, Lucas Serrano van ser tamén contratados para distintos quefaceres...Esa mesma idea dun Vega impulsor e mentor da renovación da capela recóllese desde o contrato que o cabido realiza cos ensambladores Lucas Serrano e Domingo de Andrade para facer o mausoleo do altar maior da catedral; aquí dise que «han de hacer y edificar el Mausoleo del altar Mayor del santo Apóstol, para el tabernáculo que se está haciendo para la Capilla mayor... Tanto o contrato que se citou en relación con Mateo de Prado, como o que ten que ver con Lucas Serrano e Domingo Andrade levan data de 1655». GARCÍA IGLESIAS, J. M. Arte Barroco. En Galicia-Arte. XIII. A Coruña. 1993, pp. 181-183.

"CUADERNOS DE ESTUdIOS GALLEGOS", Tomo XLVII, Fascículo 113, Santiago 2000. 
Se debe citar a José Vázquez de Córdoba ${ }^{18}$, escultor, oficial de Mateo de Prado ${ }^{19}$ en 1674, que en 1697-1698 hace una imagen de San Roque y sus andas para Cespón:

"Mas da por descargo duçientos y veinte reales de la echura de la imagen de San Roque, que hiso Josephe Básques de Córdoba, maestro en Santiago; con mas çiento y dies reales que llevó Francisco de Andrade, vezino ansí mesmo de Santiago, por la pintura de dicha ymagen, que anvas partidas ymportan tresçientos y treinta reales».

Uno de los escultores más importantes de la historia del arte gallego, Miguel Romay ${ }^{20}$, miembro de familia de ilustres artistas, quizás el que mejor representa las distintas tendencias del barroco dieciochesco español y, además, un artista de gran repercusión, ya que en su taller se han formado otros maestros ${ }^{21}$ de la talla de Benito Silveira o Felipe de Castro, realiza para San Vicente de Cespón, en 1701-1702, las imágenes de San Francisco y San Antonio:

"Mas da por descargo dose ducados de vellón, que hazen ciento y treynta y dos reales, los quales pago a Miguel de Romai, hescultor, vezino de la ciudad de Santiago que vive junto a Santa Clara, por dos Imágines, una de San Francisco y San Antonio, que hestán en uno de los colaterales desta Iglesia».

Y, en 1703, talla otras once imágenes de menor tamaño: Santa Rosa, San Diego, San Benito, San Bernardo, San Rafael, Santo Domingo, San Cayetano, San Ignacio de Loyola, San Francisco Javier, Santo Tomás Aquino y San Pedro Nolasco:

"Mas descargo seis cientos cinquenta y seis reales que pago a Miguel de Romai, escultor vecino de la ciudad de Santiago, por onze

\footnotetext{
${ }^{18}$ COUSELO BOUZAS, J.: Galicia Artística...op. cit., p. 645.

${ }^{19}$ PÉREZ COSTANTI, P.: Diccionario de Artistas...op. cit., p. 544.

${ }^{20}$ GARCÍA IGLESIAS, J. M.: Arte Barroco. En Galicia-Arte...op. cit., p. 286.

${ }^{21}$ COUSELO BOUZAS, J. : Galicia Artística... op. cit., p. 591.
} 
imágines nuebas que se hicieron para los colaterales desta iglesia, cada una a seis ducados, que aunque importan mas se le bajaron a su compañero Juan Alonso, como se podrá ver en sus quentas y esa advertencia que quatro cientos reales destos salieron de quatro cofrades que no aceptaron la cofradía, que ya están pagos y se cargaron en las quentas de su antecesor Juan Romero».

"Que todas las imágines de sanctos nuebos fueron: San Francisco y San Antonio (que costaron ambos doze ducados cada una a seis y están descargados en las quentas que dio Andrés Tubio, mayordomo de San Roque), Santa Rosa, San Diego, San Benito, San Bernardo, San Rafael, Sancto Domingo, San Cayetano, San Ignacio de Loiola, San Francisco Xavier, Santo Tomás de Aquino y San Pedro Nolasco, que todas estas a seis ducados cada una, como las mas de arriva, importan sesenta y seis ducados, que hacen siete cientos y veinte y seis reales, con más treinta reales que llevó Miguel de Romai, escultor y maestro que las hizo, vezino de Santiago; por el exceso de algunas imágines grandes y mas obra que las otras, como fueron las referidas de Sancto Domingo, San Pedro Nolasco y la de San Rafael y San Antonio de Padua, que juntos con los dichos siete cientos y veinte y seis reales hacen siete cientos y cinquenta y seis, de los quales se descargaron a dicho Domingo García de Comba en sus quentas seiscientos y cinquenta y seis, y los otros ciento son los que ban descargados en esta partida, que son unos y otros, el coste todo que hicieron dichas imágines, que tocó a esta cofradía de Nuestra Señora, además de lo que va apuntado arriva que se descargó en la de San Roque, de manera que todas las imágines nuebas referidas son treze, de las quales se pagaron onze de los alcances desta cofradía y las otras dos por la de San Roque, según va dicho; y aunque vino parte deste dinero de los cofrades que ni quisieron aceptar la cofradía, no es fuera del alcanse final, della todo lo que fue para las imágines, pues entra en los cargos finales de los mayordomos, a quienes se cargan estos aumentos de los que no quisieron dar de dicha cofradía y se los deben tomar a quenta sus subcesores, a quienes ban descargados, pero toda esta relazión es por quanto que va dicho y solo en toda la partida se bajan los dichos cien reales de vellón».

"CUADERNOS DE ESTUDIOS GALLEGOS", Tomo XLVII, Fascículo 113, Santiago 2000. 
La fecha temprana de estas imágenes nos hace suponer que serían de las primeras obras ${ }^{22}$ que realiza porque, como dice Couselo Bouzas: «Las obras suyas son muchas y de importancia, comprendidas todas las que de el conocemos entre los años 1705 y 1735 , espacio artístico de 30 años $\rangle^{23}$.

Merece la pena resaltar la figura del entallador compostelano Antonio Afonsín ${ }^{24}$, colaborador de Romay, en trabajos como los órganos de la catedral (1705) y el retablo de la Soledad $(1705)^{25}$, o en los retablos de la iglesia de los jesuitas de Santiago $(1700)^{26}$. El contacto entre ambos es posible que ya venga de atrás, puesto que en la misma época que Romay trabaja en San Vicente de Cespón también lo está haciendo él.Afonsín, en 1701, realiza los dos retablos colaterales de la iglesia, de los cuales, uno es para la Imagen de Nuestra Señora:

«Mas da por descargo nuebe cientos reales que pago a Antonio Dafunsín, entallador, vezino de Santiago, a quenta de los dos retablos colaterales desta Iglesia. Según recibo, que del tiene, con más dos reales que dio al portador que porteó a Santiago dicho dinero, que en todo hazen nuebe cientos y dos reales, los quales se sacaron desta cofradía con beneplácito y junta de los cofrades y dicho retor, por

\footnotetext{
${ }^{22}$ Anteriores a 1711 serían los primeros treinta años de aprendizaje, de instalación dentro del mundo artístico vigente. Desde entonces, y hasta 1722, surgirían las nuevas ideas, los motivos originales, el despertar consciente de la propia personalidad. Después, ya maduro, constitúyese en uno de los más genuinos intérpretes de los afanes del último barroco. OTEROTÚÑ̃EZ, R.: «Miguel de Romay, retablista». Compostellanum, 2, (1958), p.194.

${ }^{23}$ COUSELO BOUZAS, J.: Galicia Artística...op. cit., p. 591.

${ }^{24}$ COUSELO BOUZAS, J.: Galicia Artística...op. cit., pp. 177-179.

${ }^{25}$ En case todo este traballo chega, incluso a figurar ó seu lado outro mestre. Tanto na caixa do órgano do lado norte (1705-1708) como no retábulo da Soidade (1705) aparece un tal Afonsin como «entallador», mentres que a Romai se lle dá, neste caso únicamente o cualificativo de «escultor»... 2 GARCÍA IGLESIAS, J. M.: Arte Barroco. En GaliciaArte... op. cit., p. 287.

${ }^{26}$ «... Das figuras mencionadas consérvanse tres do retábulo de Santo Ignacio e dúas do de San Francisco Xabier, aínda que a de Santiago levouse tamén para aquel. Foron labradas, sen dúbida, no obradoiro de Romai, que daquela traballaba frecuentemente con Afonsín...» GARCÍA IGLESIAS, J. M.: Arte Barroco. En Galicia-Arte... op. cit., p. 289.
}

"CUADERNOS DE ESTUDIOS GALLEGOS", Tomo XLVII, Fascículo 113, Santiago 2000. 
tener alquanzes sobrados y andaren divertidos en manos de algunos maiordomos, según se suele hazer para qualquiera partida que se saca dellos para qualquiera obra desta Iglesia y la referida, con mas razón por quanto uno de dichos retablos es para la Imagen de Nuestra Señora, de cuia advocación es esta cofradía.

Mas lo da de quinientos reales que pago al entallador Antonio de Afunsin, de Santiago a quenta de los dos retablos de los dos colaterales desta Iglesia.

Mas da por descargo quatro cientos reales que faltaban para ajustar la quenta de los dos colaterales desta Iglesia a Antonio Afuncín, entallador y vecino de Santiago, los quales, se sacaron desta cofradía como consta desta partida y de otra que ba en el descargo deste mayordomo, verbo retablos, verbo colaterales a la margen y de otra en las quentas de Andrés Tubio, mayordomo que fue de San Roque, como consta del libro de dich a cofradía, folio treinta y ocho, verbo colaterales a la margen, y de otra que se sacó de la cofradia del Santísimo Sacramento y San Vicente, siendo mayordomo el retor desta feligresía como consta del libro de quenta de dicha cofradía al folio treinta y siete verbo retablos, que todas las dichas partidas importan los dichos dos mil y cien reales, como se puede ver en las quentas y folios de dichos libros asignados, que dichas cantidades se sacaron de dichos alcanzes con beneplácito y consentimiento de los vecinos por seren cofrades y aver alquances bastantes y tener una mesa caída».

Y, en 1703, Afonsín asienta los dichos retablos laterales con ayuda de sus oficiales, de los que solamente se cita el nombre de uno, el escultor de Santiago, Jacobo Quinteiro ${ }^{27}$ :

"Mas da por descargo sincuenta reales que pago a los oficiales de Antonio Afunsín, entallador en la ciudad de Santiago, por venir a poner y asentar los dos colaterales desta Iglesia, que fue en primero de março deste presente año de siete cientos.

Mas da por descargo ciento y dies reales que entregó en dicha ocación a Jacobo de Quinteiro, oficial de dicho Afunsín, de cuia horden

\footnotetext{
${ }^{27}$ COUSELO BOUZAS, J.: Galicia Artística ...op. cit., pp. 555-556.
}

"CUADERNOS DE ESTUdIOS GALLEGOS", Tomo XLVII, Fascículo 113, Santiago 2000. 
se los entrego; los dies y seis dellos fueron para los barqueros que trajeron dicha obra por mar, desde Padrón aquí y los otros ciento para dicho Afunsín a quenta de los dichos dos colaterales, que de todo tiene recibo; de suerte que los dichos dos colaterales se consertaron en dos mil y cien reales, incluso el frontal de madera, para San Roque, excepto carretos y asentar dicha obra en la Iglesia, de los quales tiene recevido dicho Afunsín asta aqui con la partida de arriva, mil y quinientos reales que hestán descargados en la cofradía de Nuestra Señora (de que se sacaron), con beneplácito de los cofrades y de dicho rector, con que se le resta para acabar de pagárselos seiscientos reales, los quales se descargaran quando se los pagaren. Con que todo lo que se le baja en esta partida son los dichos ciento y sesenta y seis reales».

Pablo Rosende ${ }^{28}$, escultor compostelano hace el retablo mayor de Santa María de Asados en 1779:

"Como cura propio de esta feligresía de Santa María de Asados zertifico que aviendo tomado posesión de este curato en veinte y nuebe de maio del año de mil setecientos setenta y nuebe por muerte de Don Thomás de Noboa, mi antezesor, hallé la Iglesia sin retablo mayor y solo avía en el altar la custodia del Santísimo, mui vieja, la ymagen de la patrona, también mui antigua y la imagen del Señor San Roque nueba, sin otra cosa que sirviese de retablo y para pronto remedio de esta nezesidad fixe zédulas para dicha obra que se remató en Pablo Rosende, vezino de Santiago, según planta que se le dio, en la cantidad de quatro mil y sietecientos reales.

Retablo mayor tubo de coste con las ymáxenes de Santa Ana y San Blas, con la de la Asumption, quatro mil sietecientos reales».

Trabajando durante el siglo XIX, está el escultor compostelano José María Estévez ${ }^{29}$, que hace el camarín de Santa Columba de Rianxo en 1824:

\footnotetext{
${ }^{28}$ COUSELO BOUZAS, J.: Galicia Artística...op. cit., p. 601.

${ }^{29}$ COUSElO BOUZAS, J.: Galicia Artística ...op. cit., p. 286.
}

"CUADERNOS DE ESTUdIOS GALLEGOS", Tomo XLVII, Fascículo 113, Santiago 2000. 
"Ytem seiscientos reales en que se ajusto la obra del camarín de Santa Columba con el Arquitecto de Santiago Josef María Estévez.

Ytem quatrocientos sesenta y cinco reales en que se ajustó la pintura y recivió Don Domingo Porto

Ytem veinte y seis reales de jornales y gratificaciones a los que ayudaron a colocarlo. I

Ytem cinquenta reales incluso un refresco a los tres propios que condujeron la obra desde Santiago.

Ytem cinquenta y cuatro reales y medio al posadero Bernardo Vázquez por la posada y manutención del arquitecto y pintor en los días que se detubieron en esta villa para su colocación y remate de la pintura».

Hasta ahora los escultores y entalladores nombrados eran todos de Santiago, pero también se menciona a otros procedentes de zonas diferentes, un ejemplo es el escultor de Oeste, Catoira -Pontevedra-, Juan Pérez ${ }^{30}$ que hace para Santa María de Isorna el retablo mayor en 1772-1773 y lo finaliza el año siguiente:

«Iten mil reales vellón que entrego a Juan Pérez, maestro de arquitectura, vezino de la feligresía de Santa Eulalia Doeste, de cuio cargo esta hazer el retablo de la capilla maior de esta parroquial Iglesia. Según recibo que presentó firmado del susodicho, que queda en poder del Señor Rector».

"Mas se le bonifican un mil y nuebe reales vellón que pago a Juan Pérez, vezino de la feligresía de Santa Baya Doeste, maestro de arquitectura. Resto que se le debía por fábrica del retablo que se ha echo de nuevo para la Capilla Mayor de la Iglesia de esta feligresía. Según recibo que exivió firmado del citado Juan Pérez».

Para Santa María de Leiro, que limita con Isorna, ambas parroquias están próximas a la de Oeste, hace una imagen de la Virgen en 17631764:

${ }^{30}$ COUSElo BOUZAS, J.: Galicia Artística ...op. cit., p. 515.

"CUADERNOS DE ESTUDIOS GALLEGOS", Tomo XLVII, Fascículo 113, Santiago 2000. 
"Mas ciento y veinte reales que costó la fábrica de una ymagen nueba de la Virgen con su pintura. Según recivo que dio Juan Pérez de Santa Eulalia de Oeste, escultor».

Y en los dos años siguientes, también en Santa María de Leiro, trabaja en el colateral de la iglesia (1764-1766):

"Mas trescientos y cinquenta reales que dio a Juan Pérez, escultor, vezino de Sana Eulalia de Oeste, según recibo que exivió del señor dicho para quenta del colectoral del Santo, yncluso en la parroquial de esta dicha feligresía.

Mas veinte y cinco reales que dio al referido Juan Pérez para el marco que hizo para dicho colecteral.

Mas veinte y cinco reales y quartillo que costó hacer el altar, tarima y tablas para el señor y para todo lo que va aquí referido. De esta obra concurrió como otro tanto Luis de Rañó , mayordomo que fue de la cofradía del Santísimo Sacramento. Según constará de sus quentas».

El pintor pontevedrés Benito Collazo ${ }^{31}$ hace para Rianxo una imagen de su patrona Santa Columba en 1740:

"En veinte de diziembre de 1740 he entregado a Don Benito Collazo sesenta reales de vellón para cuenta del corte de una imagen de Santa Columba que encargo al sobredicho me la mande hazer de toda satisfación a un escultor que sea de habilidad, y de hecho estando satisfación doy permiso para que me la pinte el sobredicho que ansí quede de hazerlo en la cantidad de ciento veinte reales de vellón y la escultura en otro tanto poco más o menos inclusos los sesenta que lleva recivido y para que conste lo firmo como rector da una con el sobredicho.

Abiendo llegado la imagen de Santa Columba que refiere la partida de arriba, se alla que su echura costó ciento treinta reales de vellón.

${ }^{31}$ COUSELO BOUZAS, J.: Galicia Artística...op. cit., pp. 265-266.

"CUADERNOS DE ESTUDIOS GALLEGOS", Tomo XLVII, Fascículo 113, Santiago 2000. 
La pintura ciento y veinte.

$Y$ unos oxos de cristal que se le han puesto ocho reales.

La llave dos reales

Para cuio coste tengo entregado al referido pintor los sesenta reales que contiene la Primera partida esta oxa, los quales sesenta reales con diez y siete reales más estaban en mi poder a un quiñón que hizieron los mareantes el año pasado de 1739 para aumento de esta cofradía que por todo acen setenta y siete reales».

Uno de los pocos escultores locales que merece ser mencionado es Francisco Núñez ${ }^{32}$ de Boiro, que trabaja en dos parroquias, para Rianxo, en 1765 , hace una custodia de madera:

"Mas setenta y un reales que pagué a Francisco Nuñez por madera y echura de una custodia para el monumento incluso pintura, llave y cerradura».

Y, en 1786, realiza un crucero para Santa María de Asados:

"En primero de maio de mil sietecientos ochenta y seis se puso el cruzero nuevo que está delante de mi puerta, concertado con Francisco Núñez, vecino de Santa Baya de Boiro, en la cantidad de nuebecientos reales vellón, cuia obra tube por prezisa para las prozesiones de la Iglesia por no aver cruzero destinado para ellas; está en terreno propio del la iglesario, por averle echado fuera que estaba zerrado antes nada me dieron para el los fabricantes y solo emplee ducientos quarenta y tres reales que estaban en mi poder, limosna del Señor San Roque, que avían sobrado de un estandarte que se hizo nuevo para las prozesiones a costa de las limosnas que se avian ofrezido en zera...».

Por último, pero no por eso menos importante, tenemos el foco noiés, donde existen escultores y talladores de gran valía. El primero al que se debe hacer referencia es Juan Novo ${ }^{33}$, entallador; es uno de los que con

\footnotetext{
${ }^{32}$ COUSElo BOUZAS, J.: Galicia Artística...op. cit., p. 483.

${ }^{33}$ PÉREZ COSTANTI, P.: Diccionario de Artistas ... op. cit., pp. 410-411.
}

"CUADERNOS DE ESTUdIOS GALLEGOS", Tomo XLVII, Fascículo 113, Santiago 2000. 
fecha más temprana nos consta que trabaja en esta zona, después de Celma. Las últimas noticias que se tenían de este autor se correspondía con $1655^{34}$, sin embargo, en el año 1659 , ayuda a la ejecución del retablo de San Andrés de Cures:

"Mas veinte i quatro reales que dio a Juan Nobo intallador para aiuda del retablo».

Alonso Fernández ${ }^{35}$, que ha realizado gran cantidad de obras en el arciprestazgo, en San Vicente de Cespón, lleva a cabo un Santo Cristo en 1724:

"Mas da por descargo cien reales de vellón que entrego a Alonso Fernández da Gudín, vezino de la villa de Noya, para ayuda de la hechura y pintura del Santo Cristo».

En el Divino Salvador de Taragoña, talla las andas de San Salvador en 1733-1734:

"Iten se le bonifican ducientos y setenta reales que entrego a Alonso Fernández de Godín, escultor vezino de la Villa de Noia, a quenta de las andas nuebas que se hizieron para el Señor San Salvador, el referido año de mil setecientos treinta y quatro, como consta de recibo que exibe».

Y, en Santa María de Leiro, en 1741, complementa el retablo de la iglesia y, dos años después, en 1743, tasa y añade un nuevo retablo:

"Iten duzientos reales que consta por rezivos que exsivió aver entregado a Alonso Fernández Gudín, escultor, vezino de la Villa de Noya, por razón de cumplementar el retablo de la Iglesia».

\footnotetext{
${ }^{34}$ «Las últimas noticias recogidas acerca del artista Juan Novo, refierense a dos contratos de aprendizaje otorgados, uno en 8 de Marzo de 1650 para enseñar el oficio de escultor en el periodo de cuatro años, y por el estipendio de 16 ducados, a domingo Verde, vecino de Noya; y otro en 9 de abril de 1655, por el que admitió de aprendiz a Domingo Álvarez...» PÉREZ COSTANTI, P.: Diccionario de Artistas... op. cit., p. 411.

${ }^{35}$ COUSELO BOUZAS, J.: Galicia Artística...op. cit., p. 291.
}

"CUADERNOS DE ESTUDIOS GALLEGOS", Tomo XLVII, Fascículo 113, Santiago 2000. 
"Primeramente da en descargo ochozientos reales que pagó / a Alonso Fernández de Gudin, maestro escultor, vezino de la Villa de Noia, por la nueba tasación y añadidura del retablo maior. Según todo ello consta del rezivo que exivió y despacho que gano dicho maestro.

Mas le da de veinte y tres reales de unos hierros grandes y clavos para asegurar dicho retablo.

Mas le da de seis reales que costó el portear el referido retablo desde Noia».

No se deben olvidar los escultores Bernardo del Río Señoráns ${ }^{36}$, que en alguna ocasión colaboró con el escultor ya citado Alonso Fernánde $z^{37} y$, José Benito Malvárez ${ }^{38}$, que se supone escultor de cierta importancia teniendo en cuenta lo que cobraba ${ }^{39}$. El primero trabaja en los retablos de Bealo en 1733:

"Últimamente se le admiten un mil y sien reales de vellón, que pago por los dos retablos de los dos colectorales de la Iglesia y de dicha cantidad excivió rezivo de Bernardo del Río, vezino de la villa de Noya, maestro que los ha echo».

El segundo, José Benito Malvárez, en 1746-1747, hace para Santa María de Leiro las andillas para el santo:

"Iten ciento y sesenta reales que costaron las andillas para el santo, según consta de rezivo de Joseph Malvares, escultor que las hizo».

${ }^{36}$ COUSElo BOUZAS, J.: Galicia Artística...op. cit., p. 574.

${ }^{37}$ Hizo en 1727 en unión de Alonso Fernández, escultores ambos de Noya, el retablo mayor de Santa María de Entines. COUSELO BOUZAS, J.: Galicia Artística ...op. cit., p. 574.

${ }^{38}$ COUSELO BOUZAS, J.: Galicia Artística... op. cit., pp. 438-440.

${ }^{39}$ Figura en la Unica como escultor de Noya, de 43 años de edad, casado con Bernarda Vázquez, de 50; tenían una hija de 20 años llamada $\mathrm{M}^{\mathrm{a}}$ Manuela y otra menor de edad, dándole de sueldo al escultor cinco reales. Era por lo tanto escultor de cierta importancia, a juzgar por lo que cobraba.» COUSELO BOUZAS, J.: Galicia Artística... op. cit., pp. 438-439.

"CUADERNOS DE ESTUDIOS GALLEGOS", Tomo XLVII, Fascículo 113, Santiago 2000. 
Y por último tenemos a Hipólito Fernández Gudín ${ }^{40}$, que solamente trabaja en la parroquia deAsados en el arreglo de los altares colaterales en 1779:

«Al mismo tiempo en atención a que los colaterales estaban por pintar y su arquitectura era a lo antiguo y tenían mucho coste las pinturas a que se agregaba, que no venían con el retablo mayor por ser a lo moderno su construcción. Llamé a un escultor de Noia, cuio nombre era Don Hipólito Fernández, para que los remediare y pusiese dezentes y con efecto, los desarmó, añadió y quitó lo que le parezió conveniente, dejándolos en el estado que se ven; puso tornavoz del púlpito e hizo una caxa para la imagen de Santa Luzía, en su misma capilla. Vinieron canteros para hazer las pilastras de los dos colaterales que no las tenían. Tapeose una especie de lazena que avía a la parte del vendabal en donde estaba la Imagen de la Soledad metida en un camarín, a quien hazían notable daño las aguas que entraban por la vidriera y lo mesmo la humedad de la pared y se colocó la Imagen al colateral, según oi se halla, hizele un vestido nuevo dezente que antes no tenía y púsele cortinas».

\section{PINTURA}

Ponte Beluso no posee mucha producción pictórica; a pesar de esta escasez, los artistas que aparecen son importantes.

Podemos hablar de la existencia de dos focos predominantes: el compostelano y el noiés.

Del foco compostelano, uno de los primeros que tenemos constancia que trabaja en esta zona es Juan Bautista Celma. Artista aragonés que como dice Pérez Constanti: «Fue sin duda, uno de los más fecundos artistas que en su tiempo (último tercio del siglo XVI y los primeros años del siglo XVII) hubo en España; pues, además de las obras de su principal profesión, dedicábase a la de otros ramos del arte, figurando como entallador, estatuario, broncista, rejero y hasta «constructor de campanas». De

${ }^{40}$ COUSElO BOUZAS, J.: Galicia Artística...op. cit., pp. 302-303.

"CUADERNOS DE ESTUDIOS GALLEGOS", Tomo XLVII, Fascículo 113, Santiago 2000. 
ahí sus salidas frecuentes a varios pueblos de Galicia y Castilla, para atender a importantes obras... $\rangle^{41}$. En Araño pinta, en 1590, el retablo de la iglesia de Santa Eulalia, retablo que ya había realizado y, las imágenes de la Quinta Angustia, Santa Baya y Santa Apolonia:

"Dio mas por descargo aver pagado a Baptista Selma, pintor, diez y siete ducados que se le restaban deviendo al complimiento de lo que avya de aver por la hechura del retablo y esto dio por cédula firmada».

"Dio mas por descargo treze ducados que pago al mismo Baptista Selma por la pintura de las imágenes de la Quinta Angustia y la Santa Baya y Santa Apolonia y aquestos también por cédula firmada».

Cuando realiza estas obras en Araño ya llevaría en Compostela veintidós años ${ }^{42}$.

También se debe destacar la figura de FranciscoAndrade, pintor gallego del último tercio del siglo XVII ${ }^{43}$, vecino de Santiago, según Couselo Bouzas natural de Mondoñedo y autor del retablo de los Remedios de dicha ciudad ${ }^{44}$. Trabaja también en San Martín Pinario en una representación de San Benito, existente en un arco del Oratorio de San Felipe Neri y atribuible a él, dada la semejanza que tiene con otra realizada en el Monasterio de Vilanova de Lourenzáa ${ }^{45}$. Este pintor realiza para Cespón la pintura de la imagen de Nuestra Señora y los altares colaterales de la igle-

${ }^{41}$ PÉREZ COSTANTI, P. : Diccionario de artistas... op. cit., p. 115. VILA JATO, M. D.: Escultura Manierista. Santiago. 1983, pp. 11-47.

${ }^{42}$ «Dice el sabio López Ferreiro que «la aparición de Celma en Compostela data del año 1564 en que, como ingeniero oficial de cosas de bronce y de hacer diversas obras y púlpitos de dicho metal, se le hizo venir de Oviedo para dar las trazas y modelos de los que querían encargarse a Flandes» para la catedral; pero esta obra de los púlpitos no se lleva a cabo hasta bastantes años después, como ya veremos». PÉREZ COSTANTI, P. : Diccionario de artistas... op. cit., p. 115.

${ }^{43}$ PÉREZ COSTANTI, P. : Diccionarios de artistas... op. cit., p. 23.

${ }^{44}$ COUSELO BOUZAS, J. : Galicia Artística...op. cit., p. 186

${ }^{45}$ MONTERROSO MONTERO, J. M.: «Aproximación al estudio del patrimonio pictórico de S. Martín Pinario». Compostellanum, 3-4, (1996), pp. 504-506.

GARCÍA IGLESIAS, J. M.: «La vida de San Rosendo en la pintura de Villanueva de Lorenzana». Boletín Auriense. (1977), pp. 39-49.

"CUADERNOS DE ESTUDIOS GALLEGOS", Tomo XLVII, Fascículo 113, Santiago 2000. 
sia en el año 1696 y, entre 1697-1698, pinta la imagen y anda de San Roque. Imagen y anda en las que había colaborado con el escultor compostelano José Vázquez de Córdoba:

«Mas da por descargo çiento y dos reales que pago al pintor Andrade, vezino de Santiago para ayuda de pintar la imagen y coletorales de Nuestra Señora, que los demás a cumplimiento de los quinientos y cinquenta reales que llebó por todo, los puso el retor en esta forma: los çiento y noventa y siete que fueran de devotos y maiorales de las quadrillas desta feligresía que fueron a Castilla y los ducientos y cinquenta y uno an çido de quiñón y medio, de dicha cofradía que pedieron los de la Secada de Agueiros de devoción a Nuestra Señora; que todo ello era para hazer una corona de plata a dicha Santa Imagen y después resolvieron todos dichos devotos se enpleaze en dicha pintura, que para maior claridad los entregó el maestro Juan Careño de Canpo a dicho retor el medio quiñón entero del año de nobenta y seis y del çiento y quarenta y dos reales que todo importa lo que ba referido y solo aqui se bajan los dichos çiento y dos reales de ariva, por quanto los demás no entraron en cargo ni descargo».

«Mas da por descargo duçientos y veinte reales de la echura de la imagen de San Roque, que hiso Josephe Básques de Córdoba, maestro en Santiago; con mas çiento y dies reales que llevó Francisco de Andrade, vezino ansí mesmo de Santiago, por la pintura de dicha ymagen; que anvas partidas ymportan tresçientos y treinta reales».

También figura Manuel Landeira (1736-1790), pintor compostelano que trabajó en esta ciudad toda su vida, que no debió ser corta y que, según Murguía, es posible que fuera discípulo de García de Bouzas, fundándose en que su hijo era su compadre, lo cual indica amistad o magisterio ${ }^{46}$. Este

${ }^{46}$ COUSElo BOUZAS, J. : Galicia Artística... op. cit., pp. 406,407.

LÓPEZ VÁZQUEZ, J. M.: Arte. Gran Enciclopedia Temática de Galicia. V. Barcelona. 1988. p. 129.

LÓPEZ VÁZQUEZ, J. M.: «Pintura». SEARA MORALES, I., LÓPEZ VÁZQUEZ, J. M.: Arte Contemporáneo. En Galicia-Arte. XV. A Coruña. 1995, p. 125.

FERNÁNDEZ CASTIÑEIRAS, E.: Un siglo de pintura gallega. 1750-1850. Santiago. 1995. (Tesis doctoral Inédita)., pp. 82-99.

"CUADERNOS DE ESTUdIOS GALLEGOS", Tomo XLVII, Fascículo 113, Santiago 2000. 
artista, en 1767-1768, pinta los colaterales de la Iglesia de Leiro y, en el año 1768-1769, hace unas pinturas de la Pasión:

"Mas da en descargo mil ciento y cinquenta reales que pagó a Manuel Landeira, pintor vezino de Santiago, por haver pintando los dos colectorales de esta Iglesia, por quenta aunque costaron dos mil y trescientos entrambos, concurrió con otro tanto la cofradía de San Roque, y todo ello consta de recibo del sobredicho y el referido Andrés llebó a su poder».

"Iten ciento y cinquenta reales que costaron las pinturas de la Pasión que se ponen sobre el escalón el día de Juebes Santo y todo ello costa de recibo que dio Manuel Landeyra, pintor vezino de la ciudad de Santiago y dicho mayordomo llebó a su poder».

Son una de las pocas pinturas que aparecen en esta zona, junto a éstas de la Pasión se descubre otra del Bautismo de Cristo, de autor anónimo, en San Andrés de Cures (1869).

También se cita a Pedro Antonio Vidal ${ }^{47}$, que trabaja en Araño en el año 1783 pintando las puertas de la Iglesia:

«Item ochenta reales que pagó por el costo de la pintura de dichas, según consta de recibo dado por Pedro Antonio Vidal, pintor vezino de la citada ciudad».

Dentro del foco noiés se debe destacar al escultor Julián Fernández de Gudín, padre de Fernando e Hipólito, que también se dedicaron a la escultura $^{48}$. Este escultor pinta las andas de Nuestra Señora para Rianxo en 1730:

"Lo ciento y cinco reales que tubo de coste, la pintura de las Andas de Nuestra Señora y los veinte y dos y medio restantes para la echura y pintura de una cruz echa en madera para el pendón de dicha cofra-

${ }^{47}$ COUSELO BOUZAS, J.: Galicia Artística ... op. cit., p. 651.

FERNÁNDEZ CASTIÑEIRAS, E.: Un siglo de pintura gallega... op. cit., pp. 100-106.

LÓPEZ VÁZQUEZ, J. M.: Arte Contemporáneo. En Galicia-Arte...op. cit., p. 125.

${ }^{48}$ COUSELO BOUZAS, J.: Galicia Artística ... op. cit., pp. 302-304.

"CUADERNOS DE ESTUDIOS GALLEGOS", Tomo XLVII, Fascículo 113, Santiago 2000. 
día según una y otra partida, consta por recivo de Julián Joseph Fernández de Gudín, maestro de escultura y pintura vecino de la villa de Noya, su fecha en ella digo en esta de Rianjo, a primero de Henero del año pasado de setecientos y treinta, firmado de dicho maestro y dicho recibo se reconoció...».

Francisco Fernández Gudín, es posible que sea familiar del anterior, aunque no se han encontrado datos para afirmar tal cosa, solamente que también es de Noya y pinta la imagen de San Salvador y Nuestra Señora en 1728-1729 para Taragoña:

"Mas se le bonifican veinte y siete reales que entregó a Francisco Fernández Godín, pintor, vezino de la villa de Noia, para en quenta de ciento treinta que llevó por pintar las dos imágenes de Señor San Salvador y Ntra. Sra. de la Expectación.

Mas cinquenta y tres reales que entregó a dicho pintor por quenta de la referida pintura, los que pagó Domingo Vizente, mayordomo antezesor a este por quenta de su alcanze y como tal se los hará buenos, con cuia advertencia se le admiten aqui en data».

No se debe olvidar al pintor Bernardo Rodiño, posiblemente familiar de Antonio Rodiño, también pintor ${ }^{49}$. Trabaja en Bealo, donde pinta una custodia en 1750:

"Mas da en data seis cientos quarenta y cinco reales que tuvo de coste la pintura de la custodia, atril y demás reparos, según se entregaron a Bernardo Rodiño, pintor vezino de Noya».

En Cespón, entre 1766-1767, dora el retablo de Nuestra Señora de la Soledad y el mayor:

"Mas nueve cientos cinquenta y seis reales y ocho maravedís que puso por su parte para ayuda de dorar el retablo de Nuestra Señora de la Soledad, parte del Retablo Maior, pintar las puertas de la Iglesia

${ }^{49}$ COUSElO BOUZAS, J.: Galicia artística ... op. cit., p. 576.

"CUADERNOS DE ESTUDIOS GALLEGOS", Tomo XLVII, Fascículo 113, Santiago 2000. 
y unas andas, según recibo de Bernardo Rudiño, vezino de la Villa de Noia, su fecha veinte y seis de diziembre de sesenta y seis».

Fuera del foco noiés no se puede olvidar a Benito Collazo ${ }^{50}$, pintor pontevedrés que trabaja en Rianxo, en 1736, pintando el anda de Santa Catalina y tres marcos de altar:

«... se acordó que de los quatrocientos reales de vellón que expresa la partida tercera de la data, que llevó Benito Collazo, pintor por el oro, pintura y travajo de los tres Marcos que sirven en el altar mayor $y$ colaterales de esta iglesia, sean que quentas de esta cofradia ducientos reales, y los otros ducientos de quenta de la fábrica, y en todo lo demás se aprueba el mencionado borrador de quenta, el qual se escriva y ponga en limpio en este presente libro y a continuación de este cavildo por el presente retor y notario. Asimismo acordaron se paguen ducientos y quinze reales de vellón al pintor de la villa de Noya, en que con el está y se alla ajustado el oro, pintura y travajo de las Andas de Santa Catalina, con su porqueta y llave, como también la metad del coste que tubieron los acheros que están mandados hazer por cavildo de quatro de Junio pasado...».

Posteriormente aparece en Leiro, entre 1744-1745, pintando el retablo mayor, un Cristo, la imagen de San Andrés y una cruz plateada:

«Iten da en data duzientos y cinquenta reales que se pagaron a Benito Collazo, vezino de Pontevedra para ayuda de los mil y ochocientos en que fue conzertada la pintura del retablo maior».

"Mas veinte reales que costó la pintura del Santísimo Cristo, que está en la Sacristía».

"Mas da en descargo veinte y quatro reales que costó la pintura de San Andrés, según que todas tres partidas acreditó el dicho Juan Figueiro con rezivo del referido Collazo».

«Mas diez reales que se dieron a Benito Collazo, por pintar dicha cruz plateada».

${ }^{50}$ COUSELO BOUZAS, J. : Galicia Artística ... op. cit., pp. 265-266.

"CUADERNOS DE ESTUdIOS GALLEGOS", Tomo XLVII, Fascículo 113, Santiago 2000. 
Ha quedado para el final un artista local, el escultor Francisco Núñez, natural de Boiro ${ }^{51}$, que, en Cespón, en el año 1752-1753 retoca la pintura de Nuestra Señora:

«Mas setenta y siete reales que entregó a Francisco Núñez, escultor, para ayuda de la retocación y pintura de la imagen de Nuestra Señora».

Y, en la misma parroquia, pinta las andas de Nuestra Señora en 17541755:

«Iten cinquenta reales que entregó al maestro Francisco Núñez, por pintar las andas de Nuestra Señora, según recibo de quince septiembre de siete cientos cinquenta y cinco».

\section{ORFEBRERÍA}

La mayor parte de las obras que se incluyen en este apartado están realizadas en metales nobles y son: cálices, vinajeras, copones, cruces parroquiales y de pendón, coronas y aureolas de las distintas imágenes, algún relicario, viriles, candeleros y, composición y dorado de las ya existentes.

Se pueden definir dos focos importantes de orfebres y plateros que desarrollan su actividad en este arciprestazgo: Santiago y Padrón.

Sumamente interesante es el foco compostelano por la abundancia de artistas que trabajan en esta zona, tanto en el siglo XVIII como en el siglo XIX.

El primero es el broncista Nicolás Vidal, la importancia de este latonero se ve en que de su taller ha salido la hermosa corona de bronce que se admira en la sala real del Hospital... el 25 de mayo de 1731 le pagan para completar esta suma 350 reales, y en la libranza se le llama «Latonero de la Real Casa $)^{52}$. ParaAraño, realiza en 1755-1756, unos candeleros y una cruz:

\footnotetext{
${ }^{51}$ COUSELO BOUZAS, J.: Diccionario de artistas... op. cit., p. 483.

${ }^{52}$ COUSELO BOUZAS, J.: Galicia Artística... op. cit., p. 651.
} 
"Mas da en data quatrocientos ochenta y ocho reales y ocho maravedís que tubieron de coste los candeleros; cruz, cornicopias, composición de la lámpara y otras cosas todo de metal según recibo que ha rexcivido de Nicolás Vidal, latonero, vezino de la expresada ciudad».

Juan Nicolás del Monte, posible miembro de una familia de plateros, ya que Couselo dice: «Todos los de este apellido suponemos que son parientes, quizás Agustín padre y Nicolás y Marcos hermanos $\rangle^{53}$, trabaja en Cespón en 1746, en la fabricación de cálices, lámparas, copones y cruces:

«Da en data trescientos reales de vellón que entregó a Juan de Montes, platero, vezino de la ciudad de Santiago, según consta por recibo dado en maio de quarenta y ocho por dicho Montes a quenta de maior quantía que le devía la Iglesia de la echura de cálizes, lámpara, copón, cruzes y por otras cosas que hizo para la Iglesia, haviéndose mezclado por orden del señor governador provisor los caudales de esta cofradía y la fábrica para lo que la Iglesia necesitare».

Y, en la misma parroquia en 1747-1748, compone la cruz del pendón de Nuestra Señora y resto de la cruz parroquial:

«Mas un mil sesenta reales que entregó a Juan Nicolás del Monte, platero, vecino de la ciudad de Santiago, por la composición de la lámpara grande, cruz del pendón de Nuestra Señora y resto de la cruz parroquial, con que ha echo y compuesto para la Iglesia. Consta por recibo, su fecha cinco de diziembre del año de quarenta y ocho, firmado del mismo».

Otro orfebre importante es Antonio de San Mamed, platero que poseía comercio en Santiago ${ }^{54}$, realiza para Leiro un cáliz nuevo en $1755 \mathrm{y}$, en 1761-1762, la cruz de plata del pendón de la Virgen:

${ }^{53}$ COUSELO BOUZAS, J.: Galicia Artistica ... op. cit., pp. 461-462.

54 «En la Única figura como «platero y como tal tenía comercio de compra y venta, siendo al mismo tiempo contraste». En 1726 ya debía figurar como orfebre de nota». COUSElO BOUZAS, J. : Galicia Artística... op. cit., p. 612.

"CUADERNOS DE ESTUDIOS GALLEGOS", Tomo XLVII, Fascículo 113, Santiago 2000. 
"Iten da en data trescientos y seis reales que llevó Antonio de San Mamed, platero, vezino de Santiago, por la ynfusión de un cálix que hizo de nuevo con la copa y patena sobredorado, en cuia cantidad entran cinquenta y dos reales que les añadió de plata; por que el que antes avía estava yncapaz para su ministerio».

"Iten quatrocientos y noventa reales y medio que tuvo de coste una cruz de plata para el pendón que pesó diez y siete onzas, seis de plata y un quartillo; $y$ por su echura ciento treinta y cinco reales vellón, según todo ello consta de recibo de Antonio de San Mamed, platero, vezino de la ciudad de Santiago».

Para la feligresía de Araño, en 1755-1756, compone un incensario:

"Iten setenta reales que así mismo han suplido para la composición del Incensario, también lo acreditó con recibo del referido Don Antonio San Mamed».

Miembro de un «obradoiro» importante es Jacobo Piedra, orfebre y grabador, hermano de Ángel; estuvo relacionado con los Pecul por su matrimonio con Luisa Crespo, hermana política de D. Claudio Pecul. Es un autor con importantes obras: hizo las rejas para los costados del tabernáculo del Apóstol, y una lámpara para Santo Domingo. Este Piedra ha trabajado para muchas parroquias de las afueras de Santiago ${ }^{55}$, entre ellas dos pertenecientes a este arciprestazgo: Cures y Asados. En ambas compone la cruz parroquial. En Cures lo hace en 1770:

"Mas duzientos reales de la composición de la cruz de plata de la Parroquia. Según recibo que recivió de Jacobo de la Piedra y Suplió el señor rector».

En Asados en 1771:

«Mas de la composición de la cruz de plata parroquial a Don Jacobo de la Piedra, platero, vezino de la ciudad de Santiago, cien reales».

${ }^{55}$ COUSELO BOUZAS, J.: Galicia Artística... op. cit., pp. .530-531.

"CUADERNOS DE ESTUDIOS GALLEGOS", Tomo XLVII, Fascículo 113, Santiago 2000. 
Ventura Castro y Fabián Antonio Ordóñez, son también plateros que trabajaron para la catedral ${ }^{56}$. El primero, en 1781 , hace un cáliz para Asados:

"Compré un cáliz de moda, todo dorado con su patena y cuchara que tubo de coste mil trescientos sesenta y cinco reales y lo hizo Don Ventura de Castro platero, vezino de Santiago».

El segundo, FabiánAntonio Ordóñez, hace lo mismo paraAraño en 1783:

"Iten trescientos cinquenta y un reales de vellón que así mismo paro, procedidas de la composición de un cáliz y patena que igualmente se doraron a fuego, porque antes no lo estaban, y del coste de un relicario portátil que se ha hecho de nuevo con el dorado correspondiente que también acredito con recibo, dado por Fabián Antonio Ordóñez, platero vezino de la ciudad de Santiago».

En el siglo XIX encontramos en Santiago un miembro de una importante familia de orfebres, los Pecul: Jacobo Luis Joaquín Pecul Montenegro y Crespo; hijo de Claudio Pecul y Juana Crespo, fue bautizado el 17 de agosto de 1753, siendo apadrinado por Jacobo de Piedra y su esposa Luisa $\mathrm{Crespo}^{57}$, aprendió el oficio con su padre; se casó con la hija del escultor Ferreiro $^{58}$ y fue el sustituto de su padre en el cargo de platero del Hospital Real ${ }^{59}$. Muere en $1817^{60}$.

Jacobo Pecul hace para Araño en 1805 diversos cálices, patenas e incensarios:

"Da en data mil doscientos sesenta y quatro y con treze maravedis que a Don Jacobo Pecul Montenegro de cambio de dos cálices con sus

${ }^{56}$ COUSELO BOUZAS, J.: Galicia Artística ... op. cit., pp. 263, 484-485.

${ }^{57}$ BOUZA BREY, F.: «La fecha de nacimiento y otros datos del orfebre compostelano Francisco Pecul». Compostellanum. 2, (1964), pp. 139-140.

${ }^{58}$ MURGUÍA, M.: El Arte en Santiago... op. cit., p. 223.

${ }^{59}$ COUSELO BOUZAS, J.: Galicia Artística ... op. cit., p. 498.

${ }^{60}$ LÓPEZ VÁZQUEZ, J. M.: «Orfebrería». Arte Contemporáneo. En Galicia-Arte... op. cit., p. 91.

"CUADERNOS DE ESTUDIOS GALLEGOS", Tomo XLVII, Fascículo 113, Santiago 2000. 
patenas y cucharas y un incensario todo nuebo de plata, deducido el valor de la plata vieja y otras iguales piezas que tenia la Iglesia cuyas nuebas trajo para esta según consta del recibo quel presentó del mismo, platero. De fecha ocho de marzo del presente año».

Y, para Leiro en 1809-1810, compone la cruz del pendón y la luneta del viril:

"Veinte reales de la composición de la cruz del pendón que llevó Don Jacobo Pecul, platero de Santiago».

«Yten veinte reales que llevó Don Jacobo Pecul, platero en Santiago por componer la luneta del Viril».

Jacinto Fuentes ${ }^{61}$, es el platero que repara un incensario en 1830 para Santa Columba de Rianxo :

"Ytem es data cien reales que pagó al platero de Santiago Don / Jacinto Fuentes por la composición y limpieza del yncensario y dos cruces pequeñas de dos pendones, incluso el propio que condujo esta alhajas, que llebó cuatro reales».

Ricardo Martínez, platero compostelano, en 1895, hace el dorado y bruñido de dos cálices, patenas y ampolla para Rianxo:

"La es de ciento seis reales que pagué a Ricardo Martínez, platero de la S. I. Catedral, por dorar y bruñir dos cálices».

"La es de cincuenta y cuatro reales a Ricardo Martínez por arreglar una ampolla y dorar un par de patenas».

Se puede decir que la zona de Padrón es el otro importante foco de orfebres y plateros que trabajan en Ponte Beluso.

En primer lugar se debe citar a Alejandro Montanés, platero de Iria Flavia, que trabajó para su colegiata haciendo relicarios de plata ${ }^{62}$; para Isorna compone a lo largo de 1721-1722 una cruz y un cáliz:

\footnotetext{
${ }^{61}$ COUSELO BOUZAS, J.: Galicia Artística ... op. cit., p. 357.

${ }^{62}$ COUSElO BOUZAS, J.: Galicia Artística... op. cit., p. 460.
} 
"Primeramente da en data y su merced dicho rector le admite en data quinse reales de vellón que pagó a Alejandro Montanés, platero y vezino de la villa de Padrón por la composeción de la coruz y un cáliz de plata, según costa de recivo».

También hay que referirse a Lorenzo Freire orfebre natural y vecino de Padrón, del que, según Couselo todas las obras que se le conocen pertenecen a la Colegiata de Padrón ${ }^{63}$. En 1734 compone y dora un cáliz para Isorna:

"Item da en data treinta reales los mesmos que tubo de coste la compusición de un cáliz que fue dorar la copa por de adentro y orilla por fuera y soldar el pie que estaba quebrado y por el trabajo del maestro, según recibo que tiene de Lorenzo Freire, platero, vezino de Padrón».

Y, para Leiro, en 1740, arregla la cruz parroquial:

«Iten nobenta y tres reales que acredito con rezivo que exibió de Lorenzo Freire, platero, vezino de la Villa de Padrón por la echura de una media naranja y media caña, todo de plata para la cruz de la Iglesia, para las puntas de ellas y clabos para clavar los florones y por la echura de todo ello y blanquear dicha cruz y plata que a puesto para todo ello segundo relaciona dicho rezibo firmado del sobredicho Freire».

De Iria Flavia también es Felipe Antonio Paceiro, que en Isorna en 1751 y 1752 repara la cruz parroquial:

«Iten se le admiten noventa y quatro reales vellón de limpiar, componer y repasar la cruz de la Parroquia, según recibo que exive de Phelipe Antonio Pazeyro, platero y vecino de la villa de Padrón».

Relacionado con Paceiro está Francisco Pereira, ya que, según Couselo, en 1749 , la fábrica de Iria le paga 100 reales a éste y a Francisco Perei-

${ }^{63}$ COUSElo BOUZAS, J.: Galicia Artística... op. cit., p. 356.

"CUADERNOS DE ESTUDIOS GALLEGOS", Tomo XLVII, Fascículo 113, Santiago 2000. 
ra por limpiar la plata de las dos iglesias ${ }^{64}$. Pereira hace para Leiro, en 1767, un cáliz nuevo con su patena y dos coronitas para la Virgen:

«Mas treszientos setenta y ocho reales y medio vellón que llebó Francisco Antonio Pereira, platero, vezino del Padrón por la fábrica de un cáliz nuevo con su patena y cucharita sobredorados por la parte de adentro, en esta forma: Por la echura nobenta y seis reales, de la plata que se añadió a la vieja del otro cáliz, patena y dos coronitas de la Virgen y su hijo que se dieron por ser antiguas sus imágenes, ciento doze reales y medio y ciento y setenta por dorar la copa de dicho cáliz patena y cucharita, componer la cantidad que ba referida y todo ello más largamente consta de recibo que dio el señor rector y llebó a su poder el nominado fabriquero».

Dos excepciones a la regla general de procedencia de los artistas orfebres son: Felipe Rey, natural de Póboa do Caramiñal, que, para Bealo, en 1697, realiza la composición de un cáliz:

"Mas da por descargo ciento y cinco reales de la plata que llevó un cálix viexo que importó setenta e un reales, quarenta y quatro del travaxo del platero Phelipe Rey de la Puebla ${ }^{65}$, que fue quien lo compuso.

Mas da por descargo onçe reales de gasto que hizo dicho mayordomo y el lizenciado Carreno en quatro viaxes que fuimos a la puebla por los cáliçes».

Y, el platero pontevedrés Antonio Carballido, que es posible sea familiar de Juan Ignacio Carballido ${ }^{66}$. Antonio compone en 1768 la cruz del pendón del Santísimo de Cespón:

"Mas quinientos veinte reales de una cruz nueba de plata por recibo de Juan Antonio Carvallido, platero, vezino de Pontevedra. Su fecha, diez y ocho de agosto de sesenta y ocho».

\footnotetext{
${ }^{64}$ COUSElo BouZAS, J: Galicia Artística ... op. cit., p. 491.

${ }^{65}$ COUSELO BOUZAS, J.: Galicia Artística... op. cit., pp. 558-559.

${ }^{66}$ COUSELO BOUZAS, J.: Galicia artística ... op. cit., p. .227.
} 


\section{VISITAS}

En el capítulo titulado «visitas» se recogen solamente las noticias que se desprenden de las inspecciones periódicas realizadas por el arzobispo a las parroquias de su diócesis, en las cuales se hace referencia a arquitectura, escultura, pintura y, orfebrería.

Se debe tener presente que, en las visitas, a parte de datos artísticos, se pueden recoger otros de tipo social o económico, de sumo interés para otras disciplinas históricas. Su importancia radica, sobre todo, en la información que ofrecen sobre el estado general del templo, imágenes, retablos y ornamentos.

Dentro de la arquitectura es frecuente que se mande fayar, losar, allanar las sepulturas y calear el templo. Pero suele haber obras de mayor envergadura: como es el caso de la fábrica de San Pedro de Bealo, en la cual, en la visita del año 1709, se manda reedificar su capilla mayor:

"Y por que alló su señoría que la Capilla Mayor de dicha Iglesiay bóveda della está de mala calidad y amenazando ruina, y que aunque por la visita pasada se mandó que los patronos de dicha Iglesia la mandasen reedificar y asegurar a un término y no se ha cumplido, manda su señoría que los que lo fueren o pretendan serlo a dicho patronato, dentro de seis meses lo cumplan, con apercivimiento que pasado dicho término no haciéndolo, perderán el derecho que por qualquiera razón ayan adquerido a dicho patronato y serán declarados por no patronos en la razón de que se pasará a los mas que convenga, al seguro y deçencia de dicha capillanía y Iglesia y mas que lugar aya lugar».

En la misma parroquia, durante la visita de 1719 , se insiste en que se terminen dichas obras de reconstrucción:

"Iten por quanto emos reconozido lo que a contribuido el lizenciado del cura actual, y limosnas de los feligreses para la reedificación de la Iglesia, en la qual faltan aún algunas cosas, para su perfección, mandamos se prosiga conforme lo tenemos comunicado con el lizenciado Don Pedro Zumarristas y que se haga retablo para el altar mayor y atrio y osario».

"CUADERNOS DE ESTUDIOS GALLEGOS", Tomo XLVII, Fascículo 113, Santiago 2000. 
Otro caso singular es el de la parroquia de Santa María de Isorna, a la que, en la visita de 1725 , se le manda hacer nueva la iglesia:

"Que respecto de estarse undiendo la capilla mayor y se necesita hazer nueva Iglesia, se haga planta nueva y por lo respectivo a la capilla mayor se cite al patrono della y los feligreses se obliguen a costear el cuerpo, ayudados de el caudal del deposito y cofradías se ponga en posturas y antes de el remate se de quenta, conforme a lo mandado por la visita de el Ilustrísimo Señor Don Luis Salcedo y Azcona y que el patrono de la capilla de el Espíritu Santo ponga en ella un altar y repare y componga con la decencia necesaria al mismo tiempo que se reedificase la Iglesia, con apercivimiento se procederá a lo que aya lugar».

También en Santa Eulalia de Araño, en la visita del año 1790, se esta reedificando la iglesia parroquial:

"Asi mismo respecto la Iglesia se arruinó con todas sus capillas y actualmente se está reedificando, se le haga saber a los patronos de estas dos capillas concurran a reedificar la parte que les correponde o se convengan con el cura y vezinos en pegar alguna renta anual por razón del sitio que deven obcupar los altares de ellos so pena de que no lo haciendo quedarán privados del derecho que tenían al sitio de dichas capillas, lo que se les hará saver por el cura de la parroquia acompañado de notario que tenga aprovación ordinaria o extraordinaria par todo lo que le damos comisión en forma».

En lo que a escultura se refiere, lo más frecuente que se suele ordenar en las visitas es: hacer y reparar los retablos, y reparar, enterrar o tapar imágenes consideradas por indecentes.

Esto se ve en Santa María de Isorna, que, en 1655, se debe hacer el retablo del altar mayor:

"Otrosí mandó su merced se cumplan las obras que están mandadas hacer por las visitas pasadas demás de las quales. Mandó su merced se haga un retablo para el altar mayor de mano de un buen oficial 
para lo qual el rector ofreció dar una limosna, la qual cumplan pena excomunión mayor y con apercivimiento».

Ocurre lo mismo en San Pedro Bealo, en 1670, donde se manda hacer un retablo para la iglesia:

"Otrosí porque dicha Iglesia necesita de un retablo y la fábrica es pobre y no tiene de que hacerlo, mandó su merced que vezinos de dicha feligresía repartan entre sí lo que importare dicho retablo y hagan hacer y poner en dicha Iglesia con su custodia dentro de seis meses...».

En Araño, por su parte, en el año de 1669, se ven obligados a tapar unas imágenes:

"Asimismo aviendo su merced visitado la capilla de Santa María de Nadal sita en esta dicha feligresía que fundó el canónigo Don Juan de Santiago Figueroa alló su merced que los tres niños de bulto que están en el retablo, en lo alto de el están indezentes por estar desnudos y que los han de sacar de la capilla. An echo vicio por medio de ellos y que respeto de se el peso muy grande por ser toda la bóbeda de piedra puede correr mucho riesgo el edificio, mandava se les ponga un belo de tafetán de medio cuerpo abaxo y que al patrón de dicha capilla con asistencia del rector de dicha feligresía aga se vean dichos arcos por ánimo de obrar el qual devajo de juramento declare si corre riesgo dicha fábrica y declarando que le puede tener dicho rector avise a su merced para que compela a dicho patrón a que le ponga con toda seguridad y que dicho rector notifiqué lo contenido en este auto a dicho patrón».

En esta misma parroquia también se mandan enterrar imágenes, como la de un Santo Angel, en 1740, y, una efigie de Nuestra Señora, en 1791:

"Iten manda su Ilustrísima que la imagen de un Santo Angel, que está en un colateral de la Epístola y es mui impropio, se entierre haziendo un oyo profundo en el pórtico de la Iglesia».

«Hai también en el lugar de Araño, términos de esta parroquia una capilla con la advocación de Nuestra Señora, tiene de pensión una

"CUADERNOS DE ESTUdIOS GALLEGOS", Tomo XLVII, Fascículo 113, Santiago 2000. 
misa diaria, fundada por el canónigo fundada por Don Juan de Santiago y Figueroa con la condución de que dicha misa debe dezirse por tres capellanes alternativamente. Su patronato se halla en litigio, tiene auto a su favor Don Benito Bazán, está dezente a excepción de una efigie de Nuestra Señora que se halla en el altar de Natividad, la que manda se entierre. Es su actual capellán...».

En el apartado de pintura podemos destacar las obras de pintura en imágenes y retablos; así en San Andrés de Cures, en la visita de 1659, se exige que se pinte y dore el altar mayor:

«Iten por quanto halló Su Señoría Ilustrísima el retablo del altar maior de dicha yglesia por dorar y pintar y faltar al altar de Nuestra Señora frontal decente, sobrando a dicha cofradia el alcance de arriva sin necesidad de el, por tanto mandó Su Señoría Ilustrísima que de dicho cofradía y se emplea en lo dicho y lo demás que fuere menester».

También ocurre lo mismo en San Pedro de Bealo y en Taragoña en el año 1733, y en Araño en 1750, donde se manda pintar el retablo de San Francisco:

"Iten manda su merced que respecto la fábrica tiene bastante caudal que a costa de el se pinte el retablo de la Capilla Mayor.»

"Iten manda su merced que en aviendo caudales sufizientes se pinte el retablo de la capilla mayor.»

"Visitó asimismo su Ilustrísima la capellanía de San Francisco que en esta Iglesia y colateral del evangelio fundó en el año de setezientos $y$ doce Don Domingo de Abuín ante Francisco Torrado Mariño con quatro misas anuales de cuia escriptura de Fundación hai copia con los papeles de esta Iglesia y aviendo Phelipe Calbo patrono de esta capilla hizo constar del cumplimiento para certificación de Don Juan Antonio Rodríguez presbiteros en atención a no tener parte que pueda ser capellán y ser cláusula de la fundación que en este caso cumpla con mandar decir dichas misas y respecto el altar necesita otra ara, manda su ilustrísima que el cura entierre la que hai y ponga otra el patrono y que este pinte el retablo, todo dentro de dos meses y el frontal».

"CUADERNOS DE ESTUdiOS GALLEGOS", Tomo XLVII, Fascículo 113, Santiago 2000. 
En lo referente a orfebrería, la mayor parte de los mandatos son relativos a: hacer inventarios de las alhajas de las parroquias; a la reparación y dorado de cálices, copones, patenas, vinajeras, incensarios, relicarios, cruces y cruces parroquiales; $y$, en menor medida, a obras nuevas.

Como ejemplo de esto, está la visita del año 1659 a Santa Eulalia de Araño, en la que se manda hacer un relicario:

"Mando su merced se agan las obras que están mandadas hacer en la visita pasada y lo mesmo un relicario de plata en que se lleva el Santísimo a los enfermos y las más obras que el rector le pareciere que lo aga el mayordomo dentro de dos meses, pena de los dichos, sola por pena de excomunión mayor lo mando y firmo».

O, la del año 1639, en la que se manda hacer un cáliz nuevo:

"Otrosí mandó su merced que los cálices que ai en la dicha yglesia los dos más pequeños se fundan ambos y dos con sus patenas y del hagan uno bueno para el servicio de dicha yglesia, lo qual cumplan dentro de dos meses pena de excomunión y con aperçevimiento».

En la visita a la parroquia de Santa Eulalia de Araño, en el año 1611, hay un caso anecdótico, se manda a los herederos del rector devolver un cáliz:

«Iten por quanto Francisco de Santiago, rector del dicho beneficio se murió sin manda y declaro delante su merced Juan Quintáns, mayordomo que es al presente avía otro cáliz de más de los tres y estaba en casa del dicho rector, mando su merced se notifique a los herederos que fincaron del dicho rector lo entreguen al dicho mayordomo para ello dar quenta quando se le pida y se lo entreguen so pena de excomunión mayor y de quatro días y el mayordomo haga las diligencias debaxo la mesma pena».

"CUADERNOS DE ESTUDIOS GALLEGOS", Tomo XLVII, Fascículo 113, Santiago 2000. 